\title{
Meningkatkan hasil belajar matematika pada pokok bahasan operasi hitung bilangan pecahan melalui model pembelajaran kooperatif tipe team assisted individualization (TAI) pada siswa kelas VII-C SMP Negeri 9 Malang
}

\author{
Emma Setyowati, Abadyo* \\ Universitas Negeri Malang, Jl. Semarang No. 5 Malang, Jawa Timur, Indonesia \\ *Penulis korespondensi, Surel: abadyo.fmipa@um.ac.id
}

Paper received: 01-11-2021; revised: 15-11-2021; accepted: 30-11-2021

\begin{abstract}
Abstrak
Tujuan penelitian ini adalah untuk meningkatkan hasil belajar matematika siswa kelas VII-C SMP Negeri 9 Malang pada pokok bahasan operasi hitung bilangan pecahan dengan menggunakan model pembelajaran kooperatif tipe Team Assisted Individualization (TAI). Penelitian ini merupakan penelitian tindakan kelas dan pendekatan penelitian yang digunakan adalah pendekatan kualitatif. Hasil penelitian ini menunjukkan bahwa pembelajaran kooperatif tipe TAI dapat meningkatkan hasil belajar. Peningkatan ini ditunjukkan dengan rata-rata nilai kuis sebelum tindakan adalah 65.21 menjadi 70.11 pada siklus I dan 78.52 pada siklus II. Sehingga dari hasil tersebut disimpulkan bahwa penerapan pembelajaran kooperatif tipe TAI dapat meningkatkan hasil belajar siswa kelas VII-C SMP Negeri 9 Malang yang dilaksanakan melalui 8 komponen, yaitu teams, placement test, teaching group, student creative, team study, whole class unit, facts test, dan team scores and team recognition.
\end{abstract}

Kata kunci: tipe TAI; hasil belajar

\section{Pendahuluan}

Sebagian besar siswa menganggap matematika sebagai mata pelajaran yang sulit dan kurang diminati (Hudojo, 2005). Salah satu penyebab pelajaran matematika kurang diminati oleh siswa berkaitan dengan metode guru dalam pembelajaran matematika. Selain itu, matematika merupakan salah satu mata pelajaran sekolah yang sulit dipahami siswa pada umumnya, karena objek kajian matematika sifatnya abstrak dan hanya ada dalam mental atau pikiran yang mempelajarinya. Meskipun demikian, bila sajian materi matematika itu dikemas sedemikian rupa dengan pendekatan pembelajaran tertentu, maka akan dapat meningkatkan pemahaman siswa terhadap materi yang akan dipelajarinya.

Operasi hitung bilangan pecahan merupakan materi dari mata pelajaran matematika SMP. Menurut Kurikulum 2006 (KTSP) materi ini diajarkan pada semester satu di kelas VII SMP. Berdasarkan kurikulum tersebut kajian materinya meliputi operasi penjumlahan, pengurangan, perkalian, dan pembagian pada pecahan.

Dari hasil wawancara yang dilakukan kepada guru bidang studi matematika kelas VII SMP Negeri 9 Malang ternyata materi pecahan sulit dipahami siswa. Akibatnya siswa sulit untuk menyelesaikan soal yang berkaitan dengan pecahan. Sebagai contoh dari hasil wawancara dengan siswa ditemukan bahwa siswa mengalami kesulitan dalam membandingkan dua pecahan yang berpenyebut tidak sama.

Bila kondisi tersebut tidak ditangani secara intensif oleh pengajar (guru matematika), maka siswa akan mengalami kesulitan yang lebih fatal lagi dalam memahami konsep-konsep karena pecahan ini berguna untuk materi selanjutnya yaitu konsep aljabar dalam bentuk 
pecahan. Hal ini sesuai dengan pendapat Hudojo (1990) bahwa “....mempelajari konsep B yang mendasarkan pada konsep A, seseorang perlu memahami lebih dahulu konsep A. Tanpa memahami konsep A, tidak mungkin orang tersebut akan dapat memahami konsep B".

Berdasarkan observasi dan wawancara dengan guru matematika kelas VII-C pada bulan September 2013 diperoleh informasi bahwa saat pembelajaran matematika motivasi belajar siswa sangat kurang, siswa dengan karakteristik yang sama cenderung untuk mengelompok menjadi satu dalam menyelesaikan suatu tugas, sehingga terbentuk kelompokkelompok homogen yang tidak seimbang di kelas, serta rendahnya keaktifan siswa di kelas. Hal tersebut mempengaruhi hasil belajar siswa sehingga sebagian besar siswa tidak tuntas belajar.

Salah satu model pembelajaran kooperatif yang dapat dijadikan alternatif adalah tipe TAI (Team Assisted Individualization). TAI merupakan model pembelajaran yang menarik karena menerapkan gabungan dari dua hal yaitu belajar dengan kemampuan masing-masing individu dan belajar kelompok. Di sisi lain, pembelajaran kooperatif yang lain juga ada yang menggabungkan belajar individu dan belajar kelompok, yaitu Think Pair Share (TPS). Keunggulan TAI dibandingkan dengan TPS adalah TPS kurang efektif jika diterapkan pada kelas yang jumlah siswanya banyak karena guru akan sulit untuk membimbing kelompok yang banyak. Pembelajaran kooperatif tipe TAI memiliki 8 komponen, yaitu teams, placement test, teaching group, student creative, team study, whole class unit, facts test, dan team scores and team recognition.

Berdasarkan latar belakang yang telah diuraikan, maka rumusan permasalahan dalam penelitian ini adalah "Bagaimana langkah-langkah pembelajaran kooperatif tipe TAI pada pokok bahasan operasi hitung bilangan pecahan yang dapat meningkatkan hasil belajar siswa kelas VII-C SMP Negeri 9 Malang?" dan "Bagaimana peningkatan hasil belajar siswa kelas VIIC SMP Negeri 9 Malang terhadap penerapan model pembelajaran kooperatif tipe TAI pada pokok bahasan operasi hitung bilangan pecahan?".

Tujuan penelitian ini adalah untuk meningkatkan hasil belajar matematika siswa kelas VII-C SMP Negeri 9 Malang pada pokok bahasan operasi hitung bilangan pecahan dengan menggunakan model pembelajaran kooperatif tipe Team Assisted Individualization (TAI). Hasil belajar adalah skor yang diperoleh siswa pada akhir pembelajaran dalam setiap siklus yaitu berupa nilai kuis. Hasil belajar siswa dikatakan meningkat apabila skor rata-rata akhir siswa setelah diimplementasikan model pembelajaran kooperatif tipe TAI dari siklus ke siklus mengalami peningkatan. Dengan kriteria ketuntasan minimal yang ditetapkan oleh sekolah yaitu 73 dan dicapai oleh $80 \%$ dari jumlah siswa dalam kelas.

\section{Metode}

Penelitian ini merupakan penelitian tindakan kelas dan pendekatan penelitian yang digunakan adalah pendekatan kualitatif. Data yang diambil dalam penelitian ini meliputi: 1) data hasil belajar; 2) data hasil observasi; 3) data hasil catatan lapangan; dan 4) data hasil wawancara.

Data yang dianalisis meliputi data hasil belajar dan data hasil observasi. Hasil belajar siswa dianalisis secara deskriptif dengan menghitung selisih antara nilai tes dasar yaitu berupa nilai kuis sebelumnya dan nilai tes akhir yaitu berupa nilai kuis pada setiap akhir siklus, dihitung dengan menggunakan rumus: 


$$
\mathrm{H}=\mathrm{NA}-\mathrm{ND}
$$

$$
\text { Keterangan: } \quad \begin{aligned}
\mathrm{H} & =\text { hasil belajar } \\
& \mathrm{NA}=\text { nilai tes akhir } \\
\mathrm{ND} & =\text { nilai tes dasar }
\end{aligned}
$$

Skor yang ditargetkan disesuaikan dengan kriteria ketuntasan belajar minimum yang telah ditetapkan sekolah yaitu 73. Ketuntasan akan tercapai jika 80\% siswa tuntas belajar. Untuk menghitung ketuntasan belajar klasikal digunakan rumus:

$$
\text { Ketuntasan Belajar }=\frac{\sum \text { siswa yang memperoleh skor } \geq 73}{\sum \text { seluruh siswa }} \times 100 \%
$$

Ketuntasan belajar dihitung untuk mengetahui peningkatan hasil belajar siswa. Pada akhir kegiatan pembelajaran kooperatif tipe TAI akan dibandingkan rata-rata skor hasil belajar sebelum tindakan dan setelah tindakan pada setiap siklus.

Sedangkan data hasil observasi yang dianalisis meliputi data hasil observasi terhadap aktivitas guru dan siswa. Data hasil observasi ini diperoleh dari pengamatan yang dilakukan oleh peneliti yang dibantu oleh observer dalam proses pembelajaran berlangsung. Pada lembar observasi tersebut terdapat beberapa tahap, dan pada tahap termuat beberapa indikator. Sehingga akan diperoleh skor-skor pada setiap indikatornya sehingga pada akhirnya akan diperoleh persentase nilai rata-rata yang dirumuskan sebagai berikut.

Persentase nilai rata-rata (NR) adalah:

$$
N R=\frac{\text { jumlah skor yang dicapai }}{\text { jumlah skor maksimum }} \times 100 \%
$$

(Arikunto, 2009: 236)

Dari persentase nilai rata-rata tersebut akan diperoleh taraf keberhasilan yang ditetapkan seperti pada Tabel 1 berikut.

Tabel 1 Taraf Keberhasilan

\begin{tabular}{ll}
\hline Taraf Keberhasilan & \\
\hline $80 \%<\mathrm{NR} \leq 100 \%$ & Sangat baik \\
$60 \%<\mathrm{NR} \leq 80 \%$ & Baik \\
$40 \%<\mathrm{NR} \leq 60 \%$ & Cukup Baik \\
$0 \%<\mathrm{NR} \leq 40 \%$ & Kurang baik \\
\hline (Sumber: Arikunto, 2009) &
\end{tabular}

\section{Hasil dan Pembahasan}

Penelitian tindakan kelas dengan metode pembelajaran Team Assisted Individualization (TAI) dilakukan dalam 2 siklus. Masing-masing siklus terdiri dari empat tahap kegiatan, yaitu perencanaan, pelaksanaan, observasi, dan refleksi. Siklus I berlangsung mulai tanggal 2 Oktober 2013 sampai dengan 8 Oktober 2013. Siklus I terdiri atas 3 kali pertemuan. Dalam 1 siklus ini materi pelajaran yang diberikan adalah operasi penjumlahan dan pengurangan pada pecahan dan di akhir siklus I diadakan kuis mengenai materi operasi penjumlahan dan pengurangan pada pecahan. 
Sedangkan siklus II berlangsung mulai tanggal 9 Oktober 2013 sampai dengan tanggal 15 Oktober 2013. Siklus II terdiri atas 3 kali pertemuan tatap muka. Dalam siklus II ini, materi pelajaran yang diberikan adalah operasi perkalian dan pembagian pada pecahan dan di akhir siklus II ini diadakan kuis mengenai materi operasi perkalian dan pembagian pada pecahan.

Menurut Slavin (2008) mekanisme pembelajaran kooperatif tipe Team Assisted Individualization (TAI) memiliki 8 komponen, yaitu teams, placement test, teaching group, student creative, team study, whole class unit, fact test, dan team scores and team recognition.

Tahapan teams. Tahapan pembelajaran pada kelompok ini diatur agar siswa berkelompok secara heterogen, dalam artian setiap kelompok terdiri atas siswa-siswa yang berkemampuan akademik berbeda. Hal ini dilakukan agar terjadi pemerataan dalam hasil belajar, sehingga siswa yang berkemampuan kurang akan dibantu oleh siswa yang berkemampuan sedang atau siswa yang berkemampuan tinggi. Karena dalam belajar kelompok, siswa bekerja sebagai tim dalam menyelesaikan sesuatu untuk mencapai tujuan bersama. Hal ini sesuai dengan pendapat Suherman (2003) yang menyatakan bahwa Cooperative Learning mencakup suatu kelompok kecil siswa yang bekerja sebagai sebuah tim untuk menyelesaikan tugas atau mengerjakan sesuatu untuk tujuan bersama lainnya.

Tahapan placement test. Placement test dapat berupa pretest atau hasil tes sebelumnya. Pada penelitian ini, guru membentuk kelompok belajar berdasarkan nilai ulangan bab sebelumnya yaitu bilangan bulat dan diranking berdasarkan perolehan nilai agar terbentuk kelompok heterogen. Hal ini sesuai pendapat Erman (2003) yang menyatakan bahwa untuk dapat mengetahui dengan baik termasuk kelompok mana seorang siswa harus ditempatkan digunakan evaluasi. Penempatan yang cocok dengan kondisi masing-masing siswa lebih memungkinkan untuk dapat mengembangkan bakat dan kemampuannya secara optimal, sehingga hasil belajarnya pun akan mencapai tujuan dengan baik.

Tahapan student creative. Siswa diminta untuk mengerjakan LKS secara individu. Pada tahapan ini, siswa dapat berlatih untuk belajar sendiri dan mengkonstruksi pengetahuan sendiri. Aisyah (2000) menyatakan bahwa belajar itu tidak sekedar mengingat informasi. Peserta didik dituntut benar-benar aktif untuk memahami dan menemukan sendiri konsepkonsep matematika yang ada. Peserta didik tidak menerima saja pengetahuan yang diberikan oleh guru.

Tahapan teaching group. Pada tahapan ini, guru tidak mengajar dengan menjelaskan materi secara utuh. Guru hanya membantu siswa membangun pengetahuan barunya dengan memberikan pertanyaan-pertanyaan pancingan sehingga siswa akan berpikir sendiri untuk membangun pengetahuan barunya tersebut. Hal ini sesuai dengan pendapat Suherman, dkk (2003:75) yang menyatakan bahwa dalam kelas konstruktivis seorang guru tidak mengajarkan kepada anak bagaimana menyelesaikan persoalan, namun mempresentasikan masalah dan mendorong siswa untuk menemukan cara mereka sendiri dalam menyelesaikan permasalahan.

Tahapan team study. Siswa berdiskusi dengan kelompok masing-masing untuk menyempurnakan atau saling melengkapi pemahaman masing-masing anggota mengenai materi yang sedang dipelajari. Sebagaimana dinyatakan Anita Lie (2005) bahwa dengan mengajarkan apa yang seseorang baru pelajari, dia akan lebih bisa menguasai atau menginternalisasi pengetahuan dan keterampilan barunya. 
Tahapan whole class unit. Tahapan ini berupa diskusi kelas. Setiap kelompok diberi kesempatan untuk melakukan presentasi. Selanjutnya hasil presentasi tersebut dibahas oleh seluruh kelas. Dalam tahapan ini, guru hanya mengontrol jalannya diskusi dan menyempurnakan materi saja pada akhir kegiatan diskusi kelas. Sebagaimana dinyatakan Suherman (2003:261) bahwa guru memimpin diskusi tentang pekerjaan kelompok itu yang membutuhkan penjelasan atau klarifikasi. Di akhir pembelajaran, guru membimbing siswa untuk menyusun kesimpulan terhadap materi yang telah dibahas pada diskusi kelas.

Tahapan fact test. Soal kuis terkait dengan materi-materi yang telah dipelajari. Berdasarkan lembar observasi tehadap aktivitas siswa dan guru, pada tahapan ini proses pembelajaran berjalan cukup baik. Ditemukan hanya beberapa siswa yang berusaha mencontek selama kuis berlangsung. Tes dilakukan pada setiap akhir siklus untuk mengetahui peningkatan hasil belajar siswa. Sebagaimana dinyatakan Erman (2003:71) bahwa tes awal dan tes akhir dimaksudkan untuk mengetahui perbedaan (kemajuan) antara kondisi awal sebelum kegiatan belajar mengajar dilakukan dan kondisi akhir sesudah kegiatan itu dilaksanakan.

Tahapan team scores and team recognition. Guru menghitung skor siswa lalu mengumumkan skor tersebut dan sekaligus memberikan penghargaan kelompok. Penghargaan kelompok diberikan pada siklus II, penghargaan yang diberikan berupa suatu piagam penghargaan dan bingkisan kepada kelompok dengan nilai peningkatan tertinggi. Sebenarnya pemberian hadiah tidaklah harus berupa barang tapi pujian, senyuman, tepukan di bahu, dan sebagainya sudah sangat berati bagi siswa. Iwa Sukiswa (dalam Zahra, 2000:33) menyatakan penghargaan dan pemberian hadiah merupakan faktor motivasi yang positif dan keuntungannya ialah dapat mengurangi rasa takut siswa dan oleh karena itu menimbulkan motivasi yang positif untuk belajar.

Penerapan pembelajaran kooperatif tipe TAI dilaksanakan sesuai dengan RPP yang telah disusun. Dari hasil lembar observasi terhadap aktivitas siswa dan guru pada siklus I dan siklus II, dapat disimpulkan bahwa hasil pelaksanaannya mengalami peningkatan atau perbaikan. Adapun perbandingan penerapan pembelajaran kooperatif tipe TAI berdasarkan tahap-tahap pembelajaran pada siklus I dan siklus II dipaparkan dalam Tabel 2 berikut.

Tabel 2 Perbandingan Lembar Observasi terhadap Aktivitas Siswa dan Guru

\begin{tabular}{lll}
\hline \multirow{2}{*}{ Siklus } & \multicolumn{2}{l}{ Rata-rata Persentase } \\
\cline { 2 - 3 } Siklus I & Aktivitas Guru & Aktivitas Siswa \\
Siklus II & $81.67 \%$ & $64.1 \%$ \\
Peningkatan & $83.195 \%$ & $69.79 \%$ \\
\hline
\end{tabular}

Dari Tabel 2 di atas, diketahui bahwa taraf keberhasilan pelaksanaan pembelajaran kooperatif tipe TAI dari aktivitas guru pada siklus I dan siklus II adalah 81.67\% dan 83.195\%. Sehingga aktivitas guru di dalam mengikuti langkah-langkah pembelajaran sesuai dengan RPP yang telah disusun mengalami peningkatan sebesar $1.525 \%$. Dengan kata lain, dalam melaksanakan pembelajaran kooperatif tipe TAI tindakan guru mengalami perbaikan dari siklus I ke siklus II. 
Dari Tabel 2 di atas, juga dapat diketahui bahwa taraf keberhasilan pelaksanaan pembelajaran kooperatif tipe TAI dari aktivitas siswa pada siklus I dan siklus II adalah $64.1 \%$ dan 69.79\%. Sehingga aktivitas siswa di dalam mengikuti langkah-langkah pembelajaran sesuai dengan yang diharapkan pada RPP yang telah disusun mengalami peningkatan sebesar 5.69\%. Dengan kata lain, dalam melaksanakan pembelajaran kooperatif tipe TAI tindakan siswa mengalami perbaikan dari siklus I ke siklus II.

Hasil belajar yang diamati dalam penelitian ini tidak hanya pada nilai yang diperoleh siswa dalam tes akhir (kuis), tapi juga proses dan keaktifan siswa dalam perolehan nilai itu. Selama proses diskusi berlangsung pada siklus I, perolehan nilai tentang keaktifan dalam kelompok hanya sedikit siswa memilih untuk mengerjakan soal secara individu dan teman lain tinggal mencontek saja daripada siswa harus menjelaskan kepada teman lain. Sedangkan pada siklus II, keaktifan kelompok lebih terlihat karena siswa ingin mendapat poin lebih dalam pembelajaran.

Pada siklus I, keaktifan siswa untuk maju ke depan baru akan muncul setelah mereka bertanya akan mendapat poin atau tidak. Begitu pula saat harus maju ke depan, siswa saling menunjuk teman satu kelompok untuk maju mempresentasikan hasil diskusi. Sedangkan pada siklus II, siswa berlomba-lomba untuk aktif maju ke depan atau sekedar memberikan tanggapan dan pertanyaan kepada kelompok yang maju presentasi.

Seperti yang telah disampaikan pada bab sebelumnya, hasil belajar siswa dapat diketahui dengan menghitung selisih antara nilai tes awal dengan tes akhir. Sedangkan untuk mengetahui ada tidaknya peningkatan hasil belajar siswa selama mengikuti pembelajaran kooperatif tipe TAI dapat diketahui dengan membandingkan hasil belajar dan ketuntasan belajar siswa yang diperoleh selama siklus I dan siklus II.

Tabel 3 Perbandingan Hasil Belajar dan Ketuntasan Belajar Siswa

\begin{tabular}{lll}
\hline Elemen & Siklus 1 & Siklus 2 \\
\hline Hasil belajar & 4.9 & 8.41 \\
Ketuntasan belajar & $69.23 \%$ & $89.74 \%$ \\
\hline
\end{tabular}

Dari Tabel 3 di atas, dapat disimpulkan bahwa hasil belajar siswa mengalami peningkatan sebesar 3.51. Artinya, nilai kuis siswa dari siklus I ke siklus II meningkat 3.51 poin. Pada siklus I, peningkatan nilai rata-rata kuis siswa sebesar 4.9, sedangkan pada siklus II peningkatan nilai rata-rata kuis siswa sebesar 8.41.

Sedangkan ketuntasan belajar siswa pada siklus I adalah 69.23\% artinya siswa yang dikatakan tuntas belajar atau yang telah mendapatkan nilai minimal 73 pada kuis sebanyak 69.23\% dari seluruh siswa kelas VII-C. Ketuntasan belajar siswa pada siklus II adalah $89.74 \%$ artinya siswa yang dikatakan tuntas atau yang telah mendapat nilai minimal 73 pada kuis sebanyak $89.74 \%$ dari seluruh siswa kelas VII-C. Sehingga peningkatan ketuntasan belajar dari siklus I ke siklus II adalah sebesar 20.51\%. Daya serap klasikal dicapai jika lebih dari atau sama dengan $80 \%$ siswa telah tuntas belajar. Pada siklus I dapat dikatakan siswa kelas VII-C belum tuntas belajar, sedangkan pada saat siklus II siswa kelas VII-C sudah tuntas belajar. Pada siklus I ketuntasan belajar belum tercapai karena siswa yang tuntas belajar 
kurang dari 80\%. Dan pada siklus II ketuntasan belajar telah tercapai karena lebih dari $80 \%$ siswa telah tuntas belajar.

Saat siklus I perolehan nilai kuis ada beberapa yang tidak murni karena siswa mencontek teman lain. Hal ini disebabkan kurangnya rasa percaya diri siswa terhadap kemampuan pribadinya. Juga disebabkan siswa tidak mempersiapkan ujian dengan belajar terlebih dahulu di rumah. Sehingga beberapa siswa mendapat nilai kurang memuaskan dan sebagian lagi mendapat nilai bagus karena hasil pemikiran siswa lain. Saat siklus II kejadian ini tidak terjadi, meski ada sebagian kecil siswa mencuri-curi waktu untuk mencontek atau sekedar mencocokkan jawaban dengan siswa lain.

Dengan adanya peningkatan hasil belajar dan ketuntasan belajar siswa maka dapat dikatakan bahwa nilai yang diperoleh siswa selama mengikuti pembelajaran kooperatif tipe TAI mengalami peningkatan. Begitu pula dengan jumlah siswa yang tuntas belajar mengalami peningkatan yang cukup berarti.

\section{Simpulan}

\subsection{Kesimpulan}

Dari penelitian yang telah dilaksanakan dan pembahasan pada bab sebelumnya, maka dapat ditarik beberapa kesimpulan sebagai berikut.

4.1.1. Langkah-langkah pembelajaran kooperatif tipe TAI pada peningkatan hasil belajar siswa adalah (a) pembentukan kelompok belajar yang beranggotakan 4-5 siswa dengan perbedaan kemampuan akademis dan jenis kelamin; (b) pemberian materi singkat oleh guru; (c) siswa diminta memahami materi dengan mengerjakan soal secara individu sehingga memiliki pemahaman dasar tentang materi yang diberikan; (d) siswa saling berbagi pemikiran dengan teman satu kelompok sehingga siswa mendapat penjelasan dan penyelesaian masalah yang lebih kompleks; (e) diskusi kelas yang memungkinkan siswa mendapat alternatif pemecahan masalah dari berbagai pendapat yang disampaikan oleh kelompok lain; (f) kuis yang dikerjakan siswa secara individu di akhir siklus untuk mengetahui hasil belajar yang diperoleh; dan (g) penghargaan kelompok.

4.1.2. Penerapan pembelajaran kooperatif tipe Team Assisted Individualization (TAI) dapat meningkatkan hasil belajar siswa kelas VII-C SMP Negeri 9 Malang pada pokok bahasan operasi hitung bilangan pecahan. Peningkatan hasil belajar ini ditunjukkan dengan ratarata nilai kuis sebelum tindakan adalah 65.21 menjadi 70.11 pada siklus I dan 78.52 pada siklus II. Ketuntasan belajar siswa juga mengalami peningkatan yang cukup berarti selama mengikuti pembelajaran kooperatif tipe TAI. Ketuntasan belajar siswa pada siklus I adalah $69.23 \%$ dan $89.74 \%$ pada siklus II.

\subsection{Saran}

Selama penelitian ini berlangsung masih terdapat kekurangan, untuk penelitian selanjutnya, peneliti memberikan beberapa saran antara lain sebagai berikut.

4.2.1. Karena LKS pada penelitian ini masih prosedural, maka disarankan untuk guru dan peneliti yang akan menerapkan pembelajaran kooperatif tipe TAI sebaiknya membuat LKS yang lebih konstruktivis agar sesuai dengan paradigma pembelajaran konstruktivistik. 
4.2.2. Untuk guru dan peneliti yang akan menerapkan pembelajaran kooperatif tipe TAI, pada awal perkenalan pembelajaran sebaiknya diperjelas proses pembelajaran yang akan dilakukan.

4.2.3. Untuk guru dan peneliti yang akan menerapkan pembelajaran kooperatif tipe TAI, dalam mengawasi semua kegiatan siswa sebaiknya diberlakukan penilaian antar teman sehingga pelaksanaan pembelajaran dapat berjalan lancar.

4.2.4. Untuk guru dan peneliti yang akan menerapkan pembelajaran kooperatif tipe TAI, sebaiknya melakukan pergantian anggota kelompok di tiap siklus untuk menghindari kebosanan siswa terhadap metode ini. Pergantian anggota kelompok ini juga berfungsi untuk membiasakan siswa berkelompok dengan siswa lain di dalam kelas.

\section{Daftar Rujukan}

Aisyah, Nyimas. (2000). Mengembangkan aktivitas siswa dalam pembelajaran matematika melalui pembelajaran kooperatif. Jurnal Forum Kependidikan, 20(1):55-66.

Arikunto, Suharsimi. (2009). Dasar-dasar evaluasi pendidikan (Edisi Revisi). Jakarta: Bumi Aksara.

Hudojo, Herman. (2005). Pengembangan kurikulum dan pembelajaran matematika. Malang: UM Press.

Lie, Anita. (2005). Cooperative learning: mempraktikkan cooperative di ruang-ruang kelas. Jakarta: PT Grasindo.

Moleong, Lexy J. (2012). Metodologi penelitian kualitatif. Bandung: Remaja Rosdakarya.

Slavin, Robert. (2005). Cooperative learning. terjemahan oleh Nurulita Yusron. 2008. Bandung: Nusa Media.

S. Ar, Erman. (2003). Evaluasi pembelajaran matematika. Bandung: JICA.

Suherman, Erman, dkk. (2003). Strategi pembelajaran matematika kontemporer. Bandung: IMSTEP JICA.

Zahra, S. (2000). Cara guru memotivasi dan pengaruhnya terhadap aktivitas siswa dalam proses pembelajaran. Jurnal Ilmu Pendidikan, 7(1):25-34. 